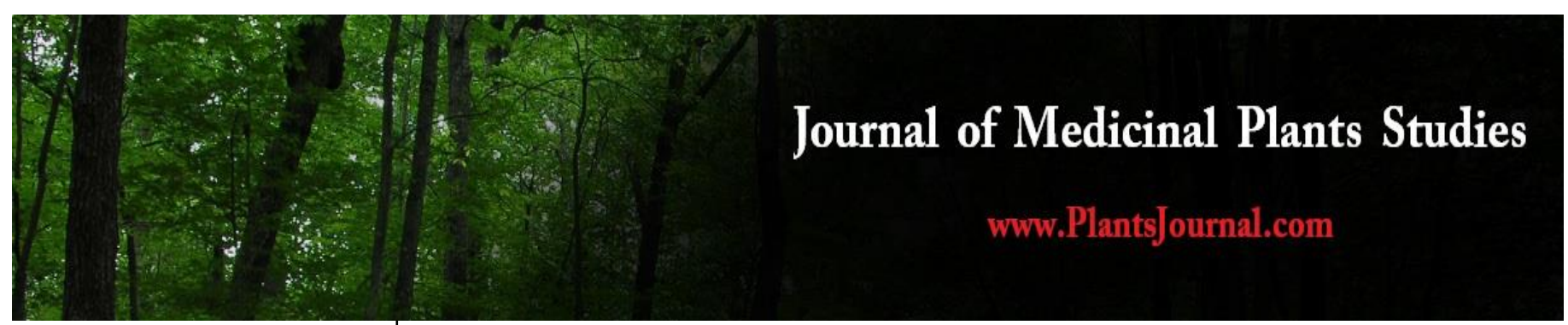

ISSN (E): 2320-3862

ISSN (P): 2394-0530

www.plantsjournal.com

JMPS 2022; 10(1): 82-86

(C) 2022 JMPS

Received: 04-11-2021

Accepted: 06-12-2021

Abhishek Konar

Department of Botany, Seacom

Skills University, Kendradangal,

Bolpur, West Bengal, India

Anusree Mondal

Department of Botany, Seacom

Skills University, Kendradangal,

Bolpur, West Bengal, India

Corresponding Author:

Abhishek Konar

Department of Botany, Seacom

Skills University, Kendradangal,

Bolpur, West Bengal, India

\section{Ethnobotanical use of plants in Birbhum district, West Bengal, India}

\section{Abhishek Konar and Anusree Mondal}

DOI: https://doi.org/10.22271/plants.2022.v10.i1b.1365

\section{Abstract}

An ethnobotanical survey was carried out among tribals of Birbhum district of West Bengal, India. Birbhum is a great biodiversity region. The exploration, identification and documentation on utilisation of ethnobotanical resources are essential for restoration and preservation of Ethnomedicinal knowledge about the plants and conservation of these species for greater interest of human society. Birbhum is a rich diversity of ethnomedicinal plants as well as a rich heritage of traditional medicine practices. A total of 36 plant species belonging and 34 families were reported to be used for treating various physical ailments.

Keywords: ethnobotanical, ethnomedicinal, Birbhum district, West Bengal

\section{Introduction}

India is known for Heritage of the knowledge of natural products. Human beings are using various parts of the plants to generate phytomedicine and these are working as panacea for modern cultures, civilizations and societies. Indian people are using medicinal plants from prehistoric period ${ }^{[1]}$. Plants are the main basis of our daily life and wild edible plants are extensively used in medicine (Ghosh, 2003; Biswas et al., 2011) by the tribe and poor inhabitant peoples in different regions of the world. About $85 \%$ of traditional medicines are plant derived ${ }^{[2]}$. Different Tribal, living mostly in the different remote forest areas and they are use different plant for medicine. From ancient period human have used plants as a source of medicine, because they are available in environment and no side effect.

80,000 plants are used for medicine, like as treat diabetes, skin treatment, diabetes, Stomach disease, Asthma, cough, Breast pain, jaundice etc. According to an estimate of WHO, approximately $80 \%$ people of developing countries rely chiefly on traditional medicine for primary healthcare (Ghosh, 2008). It means medicinal plants are the backbone of traditional or folkloric medicines. In the primary healthcare system medicinal plants are the core component for human beings that depend upon the availability, acceptability, compatibility and affordability [3, 4]. Medicinal and aromatic plants are the vital and valuable resources of primary and secondary metabolites which are used as templates for lead optimization programs and are considered to make safe and effective herbal formulations ${ }^{[5]}$. In India approximately 2000 species are used for medicinal product and vegetables.

Birbhum is one of the smallest District of West Bengal and triangular in shape. It is situated between $23^{\circ} 33^{\prime}$ and $24^{\circ} 35^{\prime}$ North latitude (Figure 1). The district is full of natural resources and with a large different tribal. A number of plant species are also used as vegetables, medicinal product by the peoples of Birbhum District of West Bengal.

\section{Study Are}

Birbhum district of West Bengal, India. Survey was conducted during the period of August, 2021 to January, 2022 and some of the places are Nalhati, Rampurhat, birchandrapur, banior, nachpahari, sultanpur, Chandramyi, Bhobanandapur, Khapur, Mallarpur, Murarai, Kurumgram, Bautia, Haridaspur, kalitha, hitalgram, paikar.

\section{Results and Discussions}

Plants are used by the local peoples for their household remedies and various purposes as well as herbal plants. The data has been verified from the ethnic people of different tribal areas who 
lived in Birbhum District. We found Local name and their used plant part and ethnobotanical uses from Birbhum's

people. These are follows:

Table 1: Some important Birbhum district traditional medicinal plants which are used for various human diseases.

\begin{tabular}{|c|c|c|c|c|}
\hline SI No. & Scientific Name \& Family & Habit & $\begin{array}{c}\text { Local Name } \\
\text { (Bengali) }\end{array}$ & Used plant part/ parts and ethnobotanical uses \\
\hline 1. & Azadirachta indica Juss. (Meliaceae) & Tree & Neem & $\begin{array}{c}\text { Young leaves used as vegetable. Neem stick used as } \\
\text { tooth brush to prevent caries. Leaf juice used in } \\
\text { diabetes. }\end{array}$ \\
\hline 2. & Ipomoea aquatica Forsk. (Convolvulaceae) & Herb & Kalmi sak & $\begin{array}{l}\text { Young twig and leaves used as vegetable. Leaf and } \\
\text { stem juice used in insect bite. }\end{array}$ \\
\hline 3. & Ficus hispida L. (Moraceae) & Tree & Dumur & $\begin{array}{c}\text { Fruits used as vegetable. White milky latex used in } \\
\text { urethristis. }\end{array}$ \\
\hline 5. & Justicia adhatoda (Acanthaceae) & Herb & Basak & Leaf juice used as expectorant to treat Asthama. \\
\hline 6. & Coriandrum sativum (Apiaceae) & Herb & Dhoney & $\begin{array}{c}\text { Young leaves used as vegetable. Seeds are used for } \\
\text { cooking. Fruits used as digestive stimulant and anti- } \\
\text { vomiting agent. }\end{array}$ \\
\hline 7. & $\begin{array}{l}\text { Hygrophila schulli (Buch.Ham) M.Ret. et. } \\
\text { S.M. Almeida (Acanthaceae) }\end{array}$ & Herb & Kulekhara & $\begin{array}{l}\text { Leaf used as vegetable. Leaf extract used to treat } \\
\text { anemia. }\end{array}$ \\
\hline 8. & $\begin{array}{c}\text { Andrographis aniculate (Brum.f.) Wall. Ex } \\
\text { Nees (Acanthaceae) }\end{array}$ & Herb & Kalmegh & $\begin{array}{c}\text { Whole plant or leaf extract used as diabetes. Young leaf } \\
\text { used as vegetable. }\end{array}$ \\
\hline 9. & Achyranthes aspera L. (Amaranthaceae) & Shrub & $\begin{array}{l}\text { Apang; } \\
\text { Chirchiti }\end{array}$ & Root is used to treat sex diseases. \\
\hline 10. & Centella asiatica $($ L.) Urban (Apiaceae) & Shrub & Thankuni & Leaves used to treat diarrhea, Cold \& cough. \\
\hline 11. & Alstonia scholaris (L.) R.B (Apocynaceae) & Tree & Chatim & $\begin{array}{l}\text { Latex prevents acidity and child constipation. Leafe } \\
\text { juice are used forgastric problems. }\end{array}$ \\
\hline 12. & Ananas comosus (L.) Merr (Bromeliaceae) & Herb & Anaras & Ripe fruits are edible. Fruit juice used against scurvy. \\
\hline 13. & Calotropis procera (Asclepiadaceae) & Shrub & Akanda & Leaves used to treat wounds. \\
\hline 14. & Tagetes erecta L. (Asteraceae) & Shrub & Genda & Leaf juice applied on cuts. \\
\hline 15. & Basella alba Stewart. (Basellaceae) & Shrub & Puin sak & Root used to treat tuberculosis. Leaf is use as vegetable \\
\hline 16. & Bombax ceiba L. (Bombacaceae) & Herb & Simul & $\begin{array}{l}\text { Root used in bone fracture and blood dysentery. Latex } \\
\text { is used in amoebioasis. }\end{array}$ \\
\hline 17. & Heliotropium indicum $\mathrm{L}$ (Boraginaceae) & Shrub & Hatisur & Root sap is used in eye treatment. \\
\hline 18. & $\begin{array}{c}\text { Shorea robusta Gaertn. F. } \\
\text { (Dipterocarpaceae) }\end{array}$ & Tree & Sal & $\begin{array}{l}\text { Young leaf use for vegetables Leaf used for plate. } \\
\text { Stem-bark is consumed to treat dysentery. }\end{array}$ \\
\hline 19. & Cajanus cajan (L.) (Fabaceae) & Shrub & Arhar & $\begin{array}{l}\text { Seeds are used in food. Leaf decoction beneficial for } \\
\text { jaundice. }\end{array}$ \\
\hline 20. & $\begin{array}{c}\text { Ricinus communis } \mathrm{L} .(\mathrm{BM}) \\
\text { (Euphorbiaceae) }\end{array}$ & Herb & Rerhi & $\begin{array}{c}\text { Seed oil used as pain killer. } \\
\text { Young twig used as vegetable. }\end{array}$ \\
\hline 21. & Tamarindus indica L. (Fabaceae) & Tree & Tentul & $\begin{array}{l}\text { Young and rip Fruits and Seeds are used for food. Ash } \\
\text { of stem bark used to cure wounds. }\end{array}$ \\
\hline 22. & Ocimum sanctum L. (Labiatae) & Herb & Tulsi & $\begin{array}{l}\text { Leaves are used in cough and cold. Young leaf bud } \\
\text { used vegetable }\end{array}$ \\
\hline 23. & Hibiscus rosa-sinensis L. (Malvaceae) & Herb & Jaba & $\begin{array}{l}\text { Leaves used to treat burning sensation, fatigue, skin } \\
\text { diseases. }\end{array}$ \\
\hline 24. & $\begin{array}{l}\text { Aegle marmelos (L.) corr ex.Roxb. } \\
\text { (Rutaceae) }\end{array}$ & Tree & Bel & $\begin{array}{l}\text { Ripe fruits and young fruits are edible. Fruit and seed } \\
\text { used in stomach. }\end{array}$ \\
\hline 25. & Psidium guajava L. (Myrtaceae) & Tree & Piyara & $\begin{array}{c}\text { Fruit used as vegetable. Ripe fruits are edible. Bark } \\
\text { used to prevent child dysentery. }\end{array}$ \\
\hline 26. & Curcuma longa L. (Zingiberaceae) & Shrub & Halud & $\begin{array}{l}\text { Rhizome paste applied to treat skin diseases and } \\
\text { inflammation. Rhizome used as vegetable. }\end{array}$ \\
\hline 27. & $\begin{array}{c}\text { Haigeng (Meich) Zingiber officinale Rosc. } \\
\text { (Zingiberaceae) }\end{array}$ & Shrub & Aada & $\begin{array}{l}\text { Rhizome used as vegetable. Rhizome paste used to treat } \\
\text { bone fracture and is digestive and stimulant. }\end{array}$ \\
\hline 28. & $\begin{array}{c}\text { Tiksal (Oraon) Tectona grandis L.f. } \\
\text { (Verbenaceae) }\end{array}$ & Tree & Segoon & $\begin{array}{c}\text { Leaf bud used as vegetable. Leaf juice used to treat } \\
\text { irregular menstrual cycle. }\end{array}$ \\
\hline 30. & Zizyphus oenoplia Mill. (Rhamnaceae) & Shrub & Sekul & $\begin{array}{c}\text { Young and Mature fruits are edible. Stem used in } \\
\text { stomachic disorder }\end{array}$ \\
\hline 31. & Datura stramonium L. Solanaceae & Shrub & Dhatura & Seed used to treat dog bite. \\
\hline 32. & $\begin{array}{l}\text { Catharanthus roseus (L.) G.Don. } \\
\text { (Apocynaceae) }\end{array}$ & Shrub & Nayantara & $\begin{array}{c}\text { Flowers are used for Puja. Whole plant or leaf extract } \\
\text { used to treat diabetes. }\end{array}$ \\
\hline 33. & $\begin{array}{c}\text { Alternanthera philoxeroides (Mart.) Griseb. } \\
\text { (Amaranthaceae) }\end{array}$ & Herb & Santi sak & $\begin{array}{l}\text { Young twig used as vegetable. Leaf used in eye and } \\
\text { hair problems. }\end{array}$ \\
\hline 34. & Xanthium strumarium L. (Asteraceae) & Herb & Okra phal & $\begin{array}{l}\text { Young twig used as vegetable. Whole plant used in } \\
\text { chronic malaria, ulcers, syphilitic and piles. }\end{array}$ \\
\hline 35 . & $\begin{array}{l}\text { Commelina benghalensis } \mathrm{L} . \\
\quad \text { (Commelinaceae) }\end{array}$ & Herb & Karos sak & $\begin{array}{c}\text { Young twig and leaves used as vegetable. Stem juice } \\
\text { used in insect bite. Leaf juice used in the blister } \\
\text { problem of eye. }\end{array}$ \\
\hline 36. & Cocos nucifera (Arecaceae) & Tree & Narkel & $\begin{array}{l}\text { Fruit used as vegetable. Used for the treatment of liver } \\
\text { complaints, to treat diseased skin, teeth. }\end{array}$ \\
\hline
\end{tabular}




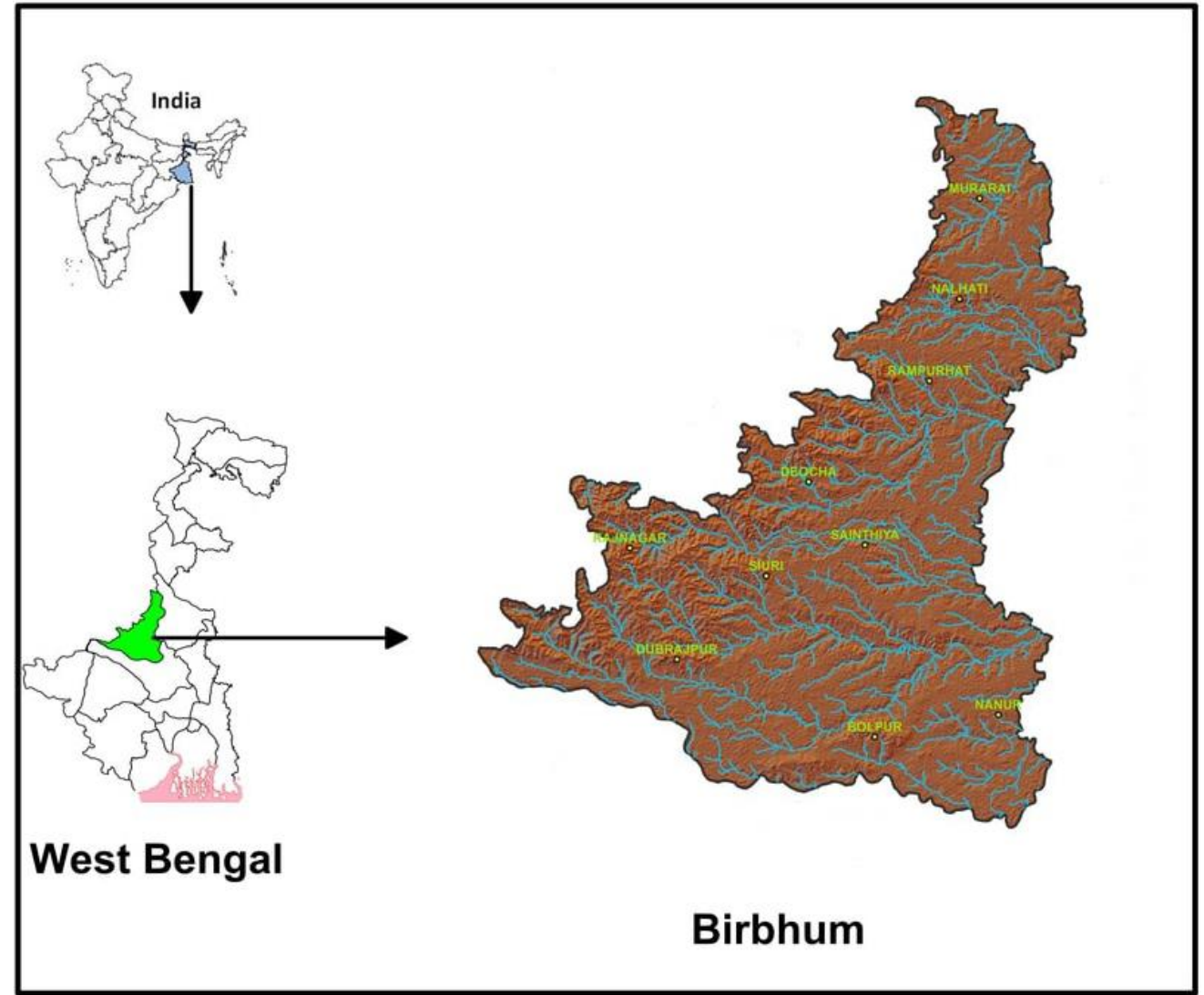

Fig 1: Survey area, Birbhum district of West Bengal, India.

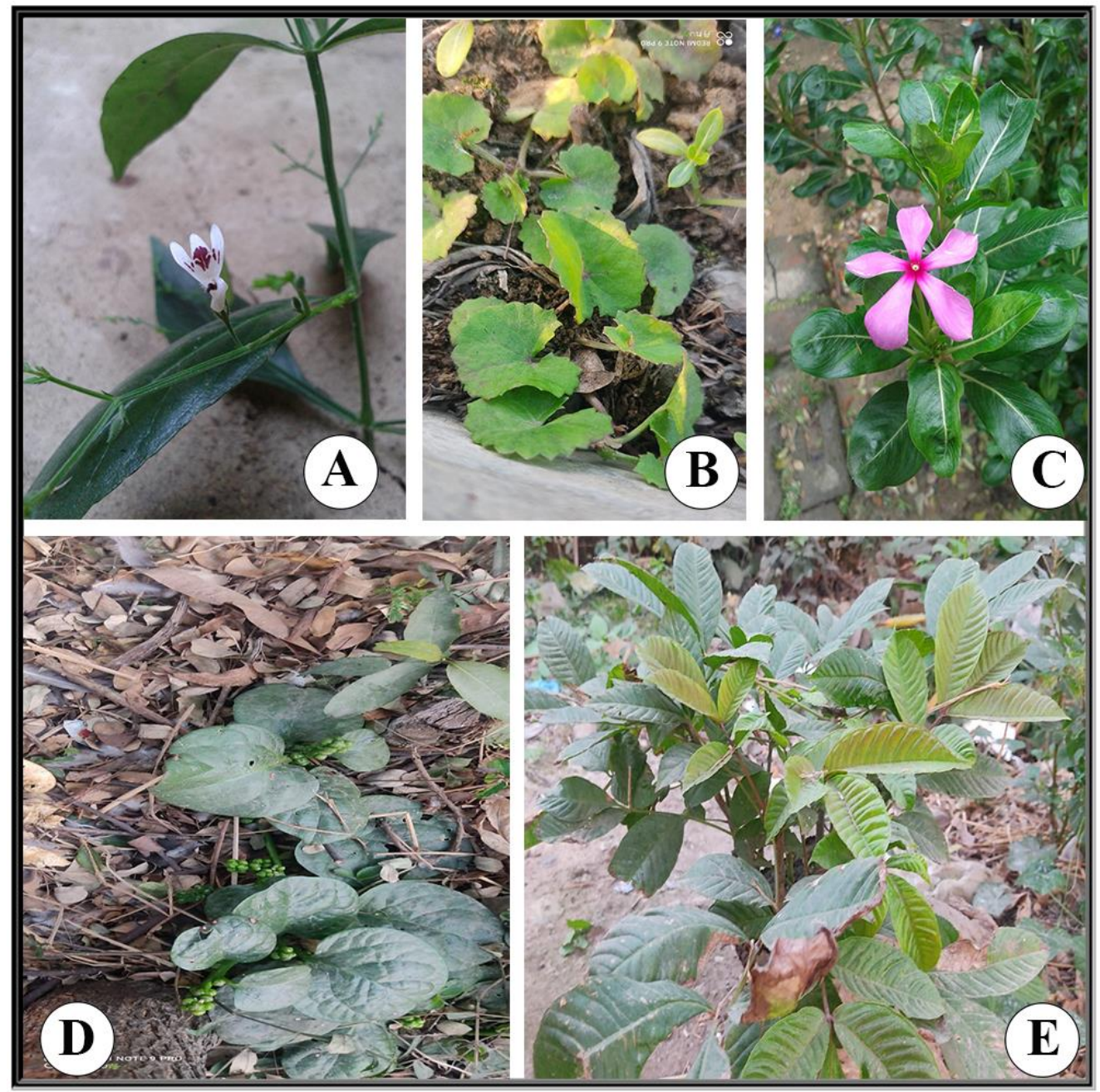

Fig 2: A. Leaf of Andrographis aniculate; B. A plant part of Centella asiatica;

C. Whole part of Catharanthus roseus; D. Leaf of Basella alba; E. A part of Psidium guajava. 


\section{Conclusion}

Almost in every corner of the Birbhum district of West Bengal, India plants were found to be used as medicine. The herbal preparations made from the traditional medicinal plants were mostly used to treat common ailments prevalent in this region like cut and wounds cough and cold, pain, Stomachache and, for treatment of jaundice and liver problems, eye treatment, treat diabetes, fatigue, skin diseases, tuberculosis. We found that a good number of the collected plants that are used for the treatment of multiple diseases. Therefore, these plants have social as well as economic importance to the daily livelihood pattern of the peoples in this region. But over exploitation of these plants may cause threatened in the wild. Further research needs to be carried out on the investigation of conservation status, socioeconomic importance and nutritional benefit of these plant species

\section{Acknowledgement}

We are thankful to the tribal people in Birbhum District of West Bengal for their valuable help in documentation of indigenous ethnomedicinal knowledge. We are thankful to Secom Skill University of Botany Department for their all kind Support

\section{References}

1. Singh U, Lahiri N. Ancient India: New Research, Oxford University Press, New Delhi, 2010.

2. Fransworth NR. Screening plants for new medicines. In: Wilson EO (ed) Biodiversity. National Academy Press, Washington DC, 1988, 83-97.

3. Md. Hossain S, Urbi Z, Sule A, Rahman KMH. Review Article Andrographis paniculata (Burm. f.) Wall.ex Nees: A Review of Ethnobotany, Phytochemistry, and Pharmacology. The Scientific World Journal, 2014, 28.

4. Md. Hossain S, Urbi Z, Sule A, Rahman KMH. Review Article Andrographis paniculata (Burm. f.) Wall.ex Nees: A Review of Ethnobotany, Phytochemistry, and Pharmacology. The Scientific World Journal, 2014, 28.

5. Ramesh Nidavani B, Mahalakshmi AM. Pharmacology of Tectona grandis Linn. Short Review. International Journal of Pharmacog and Phytochemical Research. 2014;6(1):86-90.

6. Das C, Kothari S, Muhuri A, Dutta A, Ghosh P, Chatterjee $\mathrm{S}$, et al. Clove Based Herbal Tea: development, phytochemical analysis and evaluation of antimicrobial property. Journal of Pharmaceutical Sciences and Research. 2019;11(9):3122-3129.

7. Soni P, Singh L. Marsilea quadrifola Linn. - A valuable culinary and remedial fern in Jaduguda, Jharkhand, India. Int J of Life Science and Pharma Research. 2012;2(3):99104.

8. Verma SK, Kumar A. Therapeutic uses of Withania somnifera (Ashwagandha) with a note on Withanolide and its Pharmacological actions. Asian Journal of Pharmaceutical and Clinical Research. 2011;4(1):1-4.

9. Wani SA, Kumar P. Fenugreek: A review on its nutraceutical properties and utilization in various food products. J of the Saudi Society of Agricultural Sciences. 2018;17(2):97-106.

10. Pradhan BK, Badola HK. "Ethnomedicinal plant use by Lepcha tribe of Dzongu Valley, bordering Khangchendzonga Biosphere Reserve, in North Sikkim, India", Journal of Ethnobiology and Ethnomedicine. 2008;4:22. doi:10.1186/ 1746-4269-4-22

11. Jain SK, Mudgal A. Handbook of Ethnobotany, Scientific
Publishers, Jodhpur, 1999.

12. Jain SK, Rao RR. A hand book of field and herbarium methods, Today and Tomorrow's Printers and Publishers, New Delhi and Calcutta, 1977.

13. Jain SK, Rao RR. A hand book of field and herbarium methods, Today and Tomorrow's Printers and Publishers, New Delhi and Calcutta, 1977.

14. Biswas P, Pal JK, Mondal S. Diversity, productivity and uses of non-cultivated wild edible plants of the District South Dinajpur, West Bengal. Wesleyan Journal of Research. 2011;4(2):6-19.

15. Satapathy KB, Mishra PK, Jena GSJP. Micro-botany of plants used in rituals in Jajpur district of Odisha. International Journal of Botany Studies. 2020;5(4):1-8.

16. Ghosh P, Das P, Mukherjee R, Banik S, Karmakar S, Chatterjee $S$. Extraction and quantification of pigments from Indian traditional medicinal plants: A comparative study between tree, shrub, and herb. International Journal of Pharmaceutical Sciences and Research. 2018;9(7):3052-3059.

17. Ghosh P, Dutta A, Biswas M, Biswas S, Hazra L, Nag SK, Sil S, et al. Phytomorphological, chemical and pharmacological discussions about Commelina benghalensis Linn. (Commelinaceae): A Review. The Pharma Innovation Journal. 2019;8(6):12-18.

18. Sidana J, Saini V, Dahiya S. A Review on Citrus- "The Boon of Nature". International Journal of Pharmaceutical Sciences Review and Research. 2013;18(2):20-27.

19. Saghir SA, Sadikun A, Khaw AW. Star fruit (Averrhoa carambola L): From traditional uses to pharmacological activities. Boletin Latinoamericano del Caribe de Plantas Medicinales y Aromaticas. 2013;12(3):209- 219.

20. Saghir SA, Sadikun A, Khaw AW. Star fruit (Averrhoa carambola L): From traditional uses to pharmacological activities. Boletin Latinoamericano del Caribe de Plantas Medicinales y Aromaticas. 2013;12(3):209-219.

21. Saghir SA, Sadikun A, Khaw AW. Star fruit (Averrhoa carambola L): From traditional uses to pharmacological activities. Boletin Latinoamericano del Caribe de Plantas Medicinales y Aromaticas. 2013;12(3):209-219.

22. Saghir SA, Sadikun A, Khaw AW. Star fruit (Averrhoa carambola L): From traditional uses to pharmacological activities. Boletin Latinoamericano del Caribe de Plantas Medicinales y Aromaticas. 2013;12(3):209-219.

23. Vyawahare N, Pujari R, Khsirsagar A, Ingawale D, Patil M, Kagathara V, et al. Phoenix dactylifera: An update of its indigenous uses phytochemistry and pharmacology. International Journal of Pharmacology, 2009, 7(1).

24. Alam A, Anchan K, Iwuala E. Contemporary medicinal uses of ethnomedicinally important plant: Arjuna [Terminalia arjuna (Roxb.) Wight and Arn.]. Annals of Phytomedicine: An International Journal. 2019;8(1):6369.

25. Alam A, Anchan K, Iwuala E. Contemporary medicinal uses of ethnomedicinally important plant: Arjuna [Terminalia arjuna (Roxb.) Wight and Arn.]. Annals of Phytomedicine: An International Journal. 2019;8(1):6369.

26. Nia R, Paper DH, Essien EE, Oladimeji OH, Iyadi KC, Franz G. "Investigation into in-vitro radical scavaging and in-vivo antiinflammatory potential of Tridax procumbens", Nigerian journal of physiological science. 2003;18(1):39-43.

27. Prabhu V, Vinoth Nalini G, Chidambaranathan N, Kisan S, Sudarshan. "Evaluation of anti-inflammatory and 
analgesic activity of Tridax procumbens Linn. against formalin, acetic acid and CFA induced pain models", International Journal of Pharmacy and Pharmaceutical Sciences. 2011;3:126-30.

28. Vilwanathan R, Shivashangari KS, Devak T. "Hepatoprotective activity of Tridax procumbens against d- galactosamine/lipopolysaccharide induced hepatitis in rats", Journal of Ethnopharmacology. 2005;101:55-60.

29. Sharma B, Bhat M. "Ethnobiology, Phytochemistry and Pharmacology of Usnea longissima: A Review", International Journal of Scientific Research in Biological Sciences. 2019;6(1):263-69,

30. Rajendran SM, Chandrasekar K, Sundaresan V. Ethnomedicinal lore of Valaya tribe in Seithur hills of Virudhunagar district, Tamil Nadu, India. Indian J Traditional Knowledge. 2002;1(1):59-71.

31. Choudhury S, Sharma P, Dutta Choudhury M, Dutt Sharma G. Ethnomedicinal plants used by Chorei tribes of Southern Assam, North Eastern India. Asian Pacific J. Tropical Disease. 2012, S141-S147.

32. Singh U, Lahiri N. Ancient India: New Research, Oxford University Press, New Delhi, 2010.

33. Sajem AL, Rout J, Nath M. "Tribal knowledge and Status of Some Rare and Endemic Medicinal Plants of North Cachar Hills District of Assam", Northeast India Ethnobotanical Leaflets. 2008;12:261-275.

34. Paria ND. Medicinal Plant Resources of South West Bengal, Saraswaty Press Limited, Kolkata, 2005, 39-42. 